\title{
Risk Management of Tourism Demand in South-Western Bulgaria through Correlation Analysis
}

\author{
Sophia Mirchova ${ }^{1,}$, and Kalina Durova ${ }^{2}$ \\ ${ }^{1}$ South-West University “Neofit Rilski”, Faculty of Economics, Department of Tourism, 2700 Blagoevgrad, Bulgaria \\ ${ }^{2}$ South-West University "Neofit Rilski", Faculty of Economics, Department of Finance and Accounting, 2700 \\ Blagoevgrad, Bulgaria
}

\begin{abstract}
.
Research background: The geographical location and the favorable natural features in Bulgaria are a solid precondition for the country to establish itself as a traditional tourist destination.

Purpose of the article: This research attempts to find out which parameters affect the processes of tourist demand and supply, thus creating the conditions for optimization of the tourist enterprise as an economic indicator.

Methods: The aim of the study is to make a quantitative assessment of the strength of the dependence between the factors that influence the tourism demand and receiving economic results via correlation and regression analysis. On the basis of this quantitative assessment, the risk can be managed and valuable conclusions can be drawn to improve the use and management of resources.

Findings and Value added: The empirically investigated relationships show whether the level of labor productivity of the analyzed tourist enterprises is affected by the level of employment on the tourist site. It is necessary to intensify the activities for attracting new customers such as advertising, PR., improving the image of the tourist site. All this will have a positive impact on the development of the various forms of tourism and the social situation of the population in the study region. The strong influence of the size of the current expenditures on the economic results, found in all the studied tourist sites, necessitates the improvement of the tourist demand. Managers can apply flexible approaches to managing risk related to expenditures and revenue at the tourist enterprises.
\end{abstract}

Key words: risk management; tourism demand; correlation analysis; diagnostic analysis

JEL Classification: F47; F60; H12

* Corresponding author: sophia_mirchova@abv.bg 


\section{Introduction}

The favorable geographical location of Bulgaria makes tourism one of the priority sectors of the national economy. The tourism sector provides the country's economy with about $10 \%$ of the gross national product. The main focus of the tourist product in the country is mainly on the traditional mass tourism - sea and mountain. $[1,4]$

Southwestern Bulgaria encompasses the central zones of the Balkan Peninsula, where the high mountains of Rila and Pirin rise. The relief here is intersected by vast plains and hollows. The beautiful gorges of the Struma River and the Mesta River, which have a mild Mediterranean climate, are well known. This part of Bulgaria is also characterized by hot mineral springs, which number over 200, scattered throughout the region. It was they who favored the birth and development of life here since the deepest antiquity, attested by the discovered and registered archeological sights.[5]

The natural resources, the cultural and historical heritage of the region, the rich culture and traditions are an opportunity for the conversion of this region to tourists. Supplying different models for the the development of tourism in the Southwest is useful in determining the directions for its further development as a tourist destination, as well as for developing regional strategy for tourism.[6]

\section{Methods}

The theoretical and methodological bases of the research are based on the modern achievements of the neoclassical and neo-institutional economic economy. The main methodological approaches applied in the research and analysis are the abstract-logical approach and the system approach. [13,14]Analysis, synthesis, induction and deduction have found application as their specific manifestations. Statistical methods used for research (descriptive, correlation and regression analysis), the method of scoring, etc. were used.[15, 16, 17, 18] In the processing of the empirical information and its tabular and graphical representation, the specialized statistical package (Excel, PowerPoint, Point 13 program SPS) was used.

\subsection{Basic literature and information sources}

The performed development is based on the analysis of a wide range of scientific works of Bulgarian and foreign authors, information bulletins of international organizations, international organizations. The specific econometrics applied is based on statistical data on the tourist demand in the study area. The difficulties accompanying the development are based on the theoretical bases and the choice of specific coefficients used in the multifactor analysis.

\section{Results}

When studying the influence of the quality of the hotels as a level and the income from the overnight stays, again statistically significant and determining for the tourist demand is the factor Number of shelters and accommodation 4 and 5 stars $(\mathrm{r}=0,922)$.

It is followed by 3 stars in terms of significance for the shelter.

Table 1. Correlation analysis of the means for accomodation as a quality indicator according to the income from the overnight stay calculations with SPSS software.

\section{Correlations}

\begin{tabular}{|c|c|c|c|c|}
\hline & & $\begin{array}{l}\text { Revenues from } \\
\text { overnight stays- } \\
\text { total (lv.) }\end{array}$ & $\begin{array}{c}\text { Number of shelters } \\
\text { and accommodation } 1 \\
\text { and } 2 \text { stars }\end{array}$ & $\begin{array}{c}\text { Number of shelters } \\
\text { and accommodation } 3 \\
\text { stars } \\
\end{array}$ \\
\hline $\begin{array}{l}\text { Revenues from overnight stays- } \\
\text { total (lv.) }\end{array}$ & $\begin{array}{c}\text { Pearson Correlation } \\
\text { Sig. (2-tailed) } \\
\text { N } \\
\end{array}$ & $\begin{array}{l}1 \\
5 \\
\end{array}$ & $\begin{array}{c}, 369 \\
, 541 \\
5\end{array}$ & $\begin{array}{c}447 \\
450 \\
5\end{array}$ \\
\hline $\begin{array}{c}\text { Number of shelters and } \\
\text { accommodation } 1 \text { and } 2 \text { stars }\end{array}$ & $\begin{array}{c}\text { Pearson Correlation } \\
\text { Sig. (2-tailed) } \\
\text { N }\end{array}$ & $\begin{array}{c}, 369 \\
, 541 \\
5\end{array}$ & $\begin{array}{l}1 \\
5\end{array}$ & $\begin{array}{c}, 951^{*} \\
, 013 \\
5\end{array}$ \\
\hline $\begin{array}{l}\text { Number of shelters and } \\
\text { accommodation } 3 \text { stars }\end{array}$ & $\begin{array}{c}\text { Pearson Correlation } \\
\text { Sig. (2-tailed) } \\
\text { N }\end{array}$ & $\begin{array}{c}447 \\
, 450 \\
5\end{array}$ & $\begin{array}{c}, 951^{*} \\
, 013 \\
5\end{array}$ & $\begin{array}{l}1 \\
5\end{array}$ \\
\hline $\begin{array}{c}\text { Number of shelters and } \\
\text { accommodation } 4 \text { and } 5 \text { stars }\end{array}$ & $\begin{array}{c}\text { Pearson Correlation } \\
\text { Sig. (2-tailed) } \\
\text { N }\end{array}$ & $\begin{array}{c}, 922^{*} \\
, 026 \\
5\end{array}$ & $\begin{array}{c}, 676 \\
, 210 \\
5\end{array}$ & $\begin{array}{c}, 754 \\
, 141 \\
5\end{array}$ \\
\hline
\end{tabular}

Sourse: Author's calculations. 
Table 2. Correlations

\section{Correlations}

\begin{tabular}{|cc|c|}
\hline & & $\begin{array}{c}\text { Number of } \\
\text { shelters and } \\
\text { accommodation } 4 \\
\text { and 5 stars }\end{array}$ \\
\hline \begin{tabular}{ccc|} 
Revenues from overnight stays- \\
total (lv.)
\end{tabular} & $\begin{array}{c}\text { Pearson Correlation } \\
\text { Sig. (2-tailed) } \\
\mathrm{N}\end{array}$ &, $922^{*}$ \\
&, 026 \\
\hline Number of shelters and & Pearson Correlation &, 676 \\
accommodation 1 and 2 stars & Sig. (2-tailed) &, 210 \\
& $\mathrm{~N}$ & 5 \\
\hline Number of shelters and & Pearson Correlation &, 754 \\
accommodation 3 stars & Sig. (2-tailed) &, 141 \\
& $\mathrm{~N}$ & 5 \\
\hline Number of shelters and & Pearson Correlation & 1 \\
accommodation 4 and 5 stars & Sig. (2-tailed) & \\
& $\mathrm{N}$ & 5 \\
\hline
\end{tabular}

Sourse: Author's calculations

*. Correlation is significant at the 0.05 level (2-tailed).

\section{Findings and value added}

Construction and promotion of high-class hotels and spas with a view to the fact of their determining importance in tourist demand.[7] For the purposes of the study, the correlation coefficient of foreigners and Bulgarians in relation to financial income was estimated. Determining for the tourist demand is the factor for the number of foreigners $(r=0.991)$ in relation to the financial income from the nights. Therefore, they are the determining factor in the development of a development strategy.

In the conducted correlation analysis with variables for the tourist demand by types of tourism and indicators for assessment of the impact, the following results were obtained: In case of studied factor - incomes from overnight stays are statistically significant:

- Mountain Tourism / Conditions for mountain tourism, Number of huts - 0,922

- Cultural (cognitive) tourism / Museums number - 0.926

Therefore, the determinant for the tourist demand in the South-West region is the Mountain Tourism and the CulturalCognitive Tourism. 
Table 3. Correlation analysis - tourist demand by types of tourism with studied parameter - income from overnight stays

\begin{tabular}{|c|c|c|c|c|}
\hline \multicolumn{5}{|c|}{ Correlations } \\
\hline & & $\begin{array}{l}\text { Revenues from } \\
\text { overnight } \\
\text { stays-total (lv.) }\end{array}$ & $\begin{array}{l}\text { Health tourism } \\
\text { / Presence of } \\
\text { mineral } \\
\text { springs,Numbe } \\
\text { r }\end{array}$ & \begin{tabular}{|c} 
Mountain \\
tourism / \\
Conditions for \\
mountain \\
tourism, \\
Number of huts \\
\end{tabular} \\
\hline $\begin{array}{l}\text { Revenues from overnight } \\
\text { stays-total (lv.) }\end{array}$ & $\begin{array}{c}\text { Pearson Correlation } \\
\text { Sig. (2-tailed) } \\
\text { N }\end{array}$ & $\begin{array}{l}1 \\
5\end{array}$ & $\begin{array}{c}, 209 \\
, 735 \\
5\end{array}$ & $\begin{array}{c}, 922 * \\
, 026 \\
5\end{array}$ \\
\hline $\begin{array}{c}\text { Health tourism / Presence } \\
\text { of mineral springs, } \\
\text { Number }\end{array}$ & $\begin{array}{c}\text { Pearson Correlation } \\
\text { Sig. (2-tailed) } \\
\text { N }\end{array}$ & $\begin{array}{c}, 209 \\
, 735 \\
5\end{array}$ & $\begin{array}{l}1 \\
5\end{array}$ & $\begin{array}{c}, 420 \\
, 482 \\
5\end{array}$ \\
\hline $\begin{array}{c}\text { Mountain tourism / } \\
\text { Conditions for mountain } \\
\text { tourism, Number of huts }\end{array}$ & $\begin{array}{c}\text { Pearson Correlation } \\
\text { Sig. (2-tailed) } \\
\text { N }\end{array}$ & $\begin{array}{c}922 * \\
, 026 \\
5\end{array}$ & $\begin{array}{c}, 420 \\
, 482 \\
5\end{array}$ & $\begin{array}{l}1 \\
5\end{array}$ \\
\hline $\begin{array}{l}\text { Sports tourism / ski slopes } \\
\text { with level for world } \\
\text { championship }\end{array}$ & $\begin{array}{c}\text { Pearson Correlation } \\
\text { Sig. (2-tailed) } \\
\text { N }\end{array}$ & $\begin{array}{c}, 319 \\
, 601 \\
5\end{array}$ & $\begin{array}{c}, 869 \\
, 056 \\
5\end{array}$ & $\begin{array}{c}, 631 \\
, 254 \\
5\end{array}$ \\
\hline $\begin{array}{c}\text { Spa tourism / number of } \\
\text { spa centers }\end{array}$ & $\begin{array}{c}\text { Pearson Correlation } \\
\text { Sig. (2-tailed) } \\
\mathrm{N}\end{array}$ & $\begin{array}{c}, 591 \\
, 294 \\
5 \\
\end{array}$ & $\begin{array}{c}, 800 \\
, 104 \\
5 \\
\end{array}$ & $\begin{array}{c}, 762 \\
, 134 \\
5 \\
\end{array}$ \\
\hline $\begin{array}{c}\text { Cultural (cognitive) } \\
\text { tourism / Monuments of } \\
\text { culture of world } \\
\text { importance, number }\end{array}$ & $\begin{array}{c}\text { Pearson Correlation } \\
\text { Sig. (2-tailed) } \\
\text { N }\end{array}$ & $\begin{array}{c}, 407 \\
, 497 \\
5\end{array}$ & $\begin{array}{c}-, 408 \\
, 495 \\
5\end{array}$ & $\begin{array}{c}129 \\
, 837 \\
5\end{array}$ \\
\hline $\begin{array}{c}\text { Cultural (cognitive) } \\
\text { tourism / Monuments of } \\
\text { culture of world } \\
\text { importance, number } \\
\end{array}$ & $\begin{array}{c}\text { Pearson Correlation } \\
\text { Sig. (2-tailed) } \\
\text { N }\end{array}$ & $\begin{array}{c}, 537 \\
, 351 \\
5\end{array}$ & $\begin{array}{c}-, 513 \\
, 377 \\
5\end{array}$ & $\begin{array}{c}, 509 \\
, 382 \\
5\end{array}$ \\
\hline $\begin{array}{l}\text { Cultural (cognitive) } \\
\text { tourism / Museums }\end{array}$ & $\begin{array}{c}\text { Pearson Correlation } \\
\text { Sig. (2-tailed) } \\
\text { N }\end{array}$ & $\begin{array}{c}926^{*} \\
, 024 \\
5\end{array}$ & $\begin{array}{c}-, 175 \\
, 779 \\
5\end{array}$ & $\begin{array}{c}, 766 \\
, 131 \\
5\end{array}$ \\
\hline $\begin{array}{c}\text { Ecotourism / number of } \\
\text { national parks }\end{array}$ & $\begin{array}{c}\text { Pearson Correlation } \\
\text { Sig. (2-tailed) } \\
\text { N }\end{array}$ & $\begin{array}{c}-, 365 \\
, 546 \\
5\end{array}$ & $\begin{array}{c}, 408 \\
, 495 \\
5 \\
\end{array}$ & $\begin{array}{c}-, 086 \\
, 891 \\
5\end{array}$ \\
\hline
\end{tabular}

Sourse: Author'scalculations.

\section{Recomendation}

A strategy is needed for the development of Spa tourism and development of mineral springs in view of the development of healthy tourism for foreign tourists. [21]In next research only for the elementsof the cultural tourism the following data were obtained: (Correlation matrix - detailed study of the segments of cultural tourism) - determining influence of the museums as defining tourist demand in the segment (0.926). Results for research of the factors that influence the tourist demand. According to the obtained results in the study of rank values of the variables in combination with quantitative (realized nights - number), statistical values wiyh Spearman's coefficient.[19, 20]

- Existence and realization of the conditions for facilitating the access of the disadvantaged people to the tourist sites $=1,000$

- Presence of cultural and historical sites $=0.975$

- High forest cover, diverse and well-preserved natural resources - 0.949

The analysis shows that the presence of cultural and historical objects is decisive for the tourist demand in relation to the studied variables. 
Table. 4. Nonparametric

Correlations

\begin{tabular}{|c|c|c|c|}
\hline & & & $\begin{array}{l}\text { Revenues from } \\
\text { overnight stays- } \\
\text { total (lv.) }\end{array}$ \\
\hline \multirow[t]{9}{*}{ Spearman's rho } & $\begin{array}{l}\text { Revenues from overnight stays- } \\
\text { total (lv.) }\end{array}$ & $\begin{array}{c}\text { Correlation Coefficient } \\
\text { Sig. (2-tailed) } \\
\mathrm{N}\end{array}$ & $\begin{array}{c}1,000 \\
5 \\
5\end{array}$ \\
\hline & $\begin{array}{l}\text { Health tourism / Presence of } \\
\text { mineral springs, Number }\end{array}$ & $\begin{array}{c}\text { Correlation Coefficient } \\
\text { Sig. (2-tailed) } \\
\mathrm{N}\end{array}$ & $\begin{array}{c}, 354 \\
, 559 \\
5\end{array}$ \\
\hline & $\begin{array}{l}\text { Mountain tourism / Conditions } \\
\text { for mountain tourism, Number } \\
\text { of huts }\end{array}$ & $\begin{array}{c}\text { Correlation Coefficient } \\
\text { Sig. (2-tailed) } \\
\mathrm{N} \\
\end{array}$ & $\begin{array}{c}1,000^{* *} \\
. \\
5 \\
\end{array}$ \\
\hline & $\begin{array}{l}\text { Sports tourism / ski slopes with } \\
\text { level for world championship }\end{array}$ & $\begin{array}{l}\text { Correlation Coefficient } \\
\text { Sig. (2-tailed) } \\
\mathrm{N} \\
\end{array}$ & $\begin{array}{c}, 667 \\
, 219 \\
5 \\
\end{array}$ \\
\hline & $\begin{array}{l}\text { Spa tourism / number of spa } \\
\text { centers }\end{array}$ & $\begin{array}{c}\text { Correlation Coefficient } \\
\text { Sig. (2-tailed) } \\
\mathrm{N}\end{array}$ & $\begin{array}{c}, 872 \\
, 054 \\
5\end{array}$ \\
\hline & $\begin{array}{l}\text { Cultural (cognitive) tourism / } \\
\text { Monuments of culture of world } \\
\text { importance, number }\end{array}$ & $\begin{array}{c}\text { Correlation Coefficient } \\
\text { Sig. (2-tailed) } \\
\mathrm{N}\end{array}$ & $\begin{array}{c}289 \\
, 638 \\
5\end{array}$ \\
\hline & $\begin{array}{l}\text { Cultural (cognitive) tourism / } \\
\text { Monuments of culture of world } \\
\text { importance, number }\end{array}$ & $\begin{array}{c}\text { Correlation Coefficient } \\
\text { Sig. (2-tailed) } \\
\mathrm{N}\end{array}$ & $\begin{array}{c}300 \\
, 624 \\
5\end{array}$ \\
\hline & $\begin{array}{c}\text { Cultural (cognitive) tourism / } \\
\text { Museums }\end{array}$ & $\begin{array}{c}\text { Correlation Coefficient } \\
\text { Sig. (2-tailed) } \\
\mathrm{N}\end{array}$ & $\begin{array}{c}975^{* *} \\
, 005 \\
5\end{array}$ \\
\hline & $\begin{array}{c}\text { Ecotourism / number of national } \\
\text { parks }\end{array}$ & $\begin{array}{c}\text { Correlation Coefficient } \\
\text { Sig. (2-tailed) } \\
\text { N }\end{array}$ & $\begin{array}{c}, 000 \\
1,000 \\
5\end{array}$ \\
\hline
\end{tabular}

Sourse: Author'scalculations

According to the obtained results in the study of rank values of the variables (External factors influencing the tourist demand) in combination with quantities, quantities (realized nights - number), statistically significant with the coefficient of Spearman are:

- Accessibility to national and international programs supporting the development of the sector $=1,000$

- Degree of economic activity of private entrepreneurs $=0.949$

- The economic situation and the impact on tourism - 0.900 
Table 5. Correlation analysis of the influence of internal factors on tourist demand - calculation with SPSS

Correlations

\begin{tabular}{|c|c|c|c|c|}
\hline & & & Number of beds & $\begin{array}{c}\text { Realized } \\
\text { overnight stays - } \\
\text { number Total }\end{array}$ \\
\hline \multirow[t]{6}{*}{ Kendall's tau_b } & Number of beds & $\begin{array}{c}\text { Correlation Coefficient } \\
\text { Sig. (2-tailed) } \\
\text { N }\end{array}$ & $\begin{array}{c}1,000 \\
\dot{5}\end{array}$ & $\begin{array}{c}, 800 \\
, 050 \\
5\end{array}$ \\
\hline & $\begin{array}{c}\text { Realized overnight stays - } \\
\text { number Total }\end{array}$ & $\begin{array}{c}\text { Correlation Coefficient } \\
\text { Sig. (2-tailed) } \\
\mathrm{N} \\
\end{array}$ & $\begin{array}{c}800 \\
, 050 \\
5 \\
\end{array}$ & $\begin{array}{c}1,000 \\
. \\
5\end{array}$ \\
\hline & $\begin{array}{l}\text { Existence and realization of the } \\
\text { conditions for facilitating the } \\
\text { access of people in an unequal } \\
\text { position to the tourist sites }\end{array}$ & $\begin{array}{c}\text { Correlation Coefficient } \\
\text { Sig. (2-tailed) } \\
\text { N }\end{array}$ & $\begin{array}{c}, 800 \\
, 050 \\
5\end{array}$ & $\begin{array}{c}1,000^{* *} \\
\dot{5}\end{array}$ \\
\hline & $\begin{array}{l}\text { Presence of cultural and } \\
\text { historical sites }\end{array}$ & $\begin{array}{l}\text { Correlation Coefficient } \\
\text { Sig. (2-tailed) } \\
\mathrm{N} \\
\end{array}$ & $\begin{array}{c}, 738 \\
, 077 \\
5 \\
\end{array}$ & $\begin{array}{c}949^{*} \\
, 023 \\
5\end{array}$ \\
\hline & $\begin{array}{l}\text { High forest cover, diverse and } \\
\text { well-preserved natural } \\
\text { resources }\end{array}$ & $\begin{array}{c}\text { Correlation Coefficient } \\
\text { Sig. (2-tailed) } \\
\mathrm{N} \\
\end{array}$ & $\begin{array}{c}, 894^{*} \\
, 037 \\
5 \\
\end{array}$ & $\begin{array}{c}, 894^{*} \\
, 037 \\
5 \\
\end{array}$ \\
\hline & $\begin{array}{l}\text { Presence of mineral springs, } \\
\text { RANKING VALUE - }\end{array}$ & $\begin{array}{c}\text { Correlation Coefficient } \\
\text { Sig. (2-tailed) } \\
\mathrm{N}\end{array}$ & $\begin{array}{c}738 \\
, 077 \\
5\end{array}$ & $\begin{array}{c}738 \\
, 077 \\
5\end{array}$ \\
\hline \multirow[t]{6}{*}{ Spearman's rho } & Number of beds & $\begin{array}{c}\text { Correlation Coefficient } \\
\text { Sig. (2-tailed) } \\
\mathrm{N}\end{array}$ & $\begin{array}{c}1,000 \\
5 \\
5\end{array}$ & $\begin{array}{c}900^{*} \\
, 037 \\
5\end{array}$ \\
\hline & $\begin{array}{l}\text { Realized overnight stays - } \\
\text { number Total }\end{array}$ & $\begin{array}{c}\text { Correlation Coefficient } \\
\text { Sig. (2-tailed) } \\
\mathrm{N}\end{array}$ & $\begin{array}{c}900^{*} \\
, 037 \\
5\end{array}$ & $\begin{array}{c}1,000 \\
5 \\
5\end{array}$ \\
\hline & $\begin{array}{l}\text { Existence and realization of the } \\
\text { conditions for facilitating the } \\
\text { access of people in an unequal } \\
\text { position to the tourist sites }\end{array}$ & $\begin{array}{c}\text { Correlation Coefficient } \\
\text { Sig. (2-tailed) } \\
\text { N }\end{array}$ & $\begin{array}{c}, 900^{*} \\
, 037 \\
5\end{array}$ & $\begin{array}{c}1,000^{* *} \\
. \\
5\end{array}$ \\
\hline & $\begin{array}{l}\text { Presence of cultural and } \\
\text { historical sites }\end{array}$ & $\begin{array}{c}\text { Correlation Coefficient } \\
\text { Sig. (2-tailed) } \\
\mathrm{N}\end{array}$ & $\begin{array}{c}, 872 \\
, 054 \\
5\end{array}$ & $\begin{array}{c}975^{* *} \\
, 005 \\
5\end{array}$ \\
\hline & $\begin{array}{c}\text { High forest cover, diverse and } \\
\text { well-preserved natural } \\
\text { resources }\end{array}$ & $\begin{array}{c}\text { Correlation Coefficient } \\
\text { Sig. (2-tailed) } \\
\mathrm{N} \\
\end{array}$ & $\begin{array}{c}949^{*} \\
, 014 \\
5 \\
\end{array}$ & $\begin{array}{c}949^{*} \\
, 014 \\
5 \\
\end{array}$ \\
\hline & $\begin{array}{l}\text { Presence of mineral springs, } \\
\text { RANKING VALUE - }\end{array}$ & $\begin{array}{c}\text { Correlation Coefficient } \\
\text { Sig. (2-tailed) } \\
\mathrm{N}\end{array}$ & $\begin{array}{c}, 872 \\
, 054 \\
5\end{array}$ & $\begin{array}{c}, 872 \\
, 054 \\
5\end{array}$ \\
\hline
\end{tabular}

Sourse: Author'scalculations

The analysis shows that the external factors influencing the tourist demand determining according to the studied variables is the accessibility to national and internationalprograms supporting the development of the sector and the degree of economic activity of private entrepreneurs.[9] 
Table 6. Correlation analysis of the influence of external factors on the tourist demand - calculation with SPSS

\begin{tabular}{|c|c|c|c|c|}
\hline \multicolumn{5}{|c|}{ Correlations } \\
\hline & & & Number of beds & $\begin{array}{c}\text { overnight stays - } \\
\text { number Total }\end{array}$ \\
\hline \multirow[t]{6}{*}{ Kendall's tau_b } & Number of beds & $\begin{array}{c}\text { Correlation Coefficient } \\
\text { Sig. (2-tailed) } \\
\text { N } \\
\end{array}$ & $\begin{array}{c}1,000 \\
. \\
5 \\
\end{array}$ & $\begin{array}{c}800 \\
, 050 \\
5 \\
\end{array}$ \\
\hline & $\begin{array}{l}\text { Realized overnight stays - } \\
\text { number Total }\end{array}$ & $\begin{array}{c}\text { Correlation Coefficient } \\
\text { Sig. (2-tailed) } \\
\text { N } \\
\end{array}$ & $\begin{array}{c}, 800 \\
, 050 \\
5 \\
\end{array}$ & $\begin{array}{c}1,000 \\
5 \\
5\end{array}$ \\
\hline & $\begin{array}{l}\text { Favorable geographical and } \\
\text { transport position }\end{array}$ & $\begin{array}{c}\text { Correlation Coefficient } \\
\text { Sig. (2-tailed) } \\
\mathrm{N} \\
\end{array}$ & $\begin{array}{c}949^{*} \\
, 023 \\
5 \\
\end{array}$ & $\begin{array}{c}, 738 \\
, 077 \\
5 \\
\end{array}$ \\
\hline & $\begin{array}{l}\text { Accessibility to national and } \\
\text { international programs } \\
\text { supporting the development of } \\
\text { the sector }\end{array}$ & $\begin{array}{c}\text { Correlation Coefficient } \\
\text { Sig. (2-tailed) } \\
\text { N }\end{array}$ & $\begin{array}{c}800 \\
, 050 \\
5\end{array}$ & $\begin{array}{c}1,000^{* *} \\
\cdot \\
5\end{array}$ \\
\hline & $\begin{array}{l}\text { The economic situation and the } \\
\text { impact on tourism }\end{array}$ & $\begin{array}{l}\text { Correlation Coefficient } \\
\text { Sig. (2-tailed) } \\
\mathrm{N} \\
\end{array}$ & $\begin{array}{c}600 \\
, 142 \\
5 \\
\end{array}$ & $\begin{array}{c}800 \\
, 050 \\
5 \\
\end{array}$ \\
\hline & $\begin{array}{l}\text { Degree of economic activity of } \\
\text { private entrepreneurs }\end{array}$ & $\begin{array}{l}\text { Correlation Coefficient } \\
\text { Sig. (2-tailed) } \\
\mathrm{N} \\
\end{array}$ & $\begin{array}{c}, 894^{*} \\
, 037 \\
5 \\
\end{array}$ & $\begin{array}{c}, 894^{*} \\
, 037 \\
5 \\
\end{array}$ \\
\hline \multirow[t]{6}{*}{ Spearman's rho } & Number of beds & $\begin{array}{c}\text { Correlation Coefficient } \\
\text { Sig. (2-tailed) } \\
\mathrm{N} \\
\end{array}$ & $\begin{array}{c}1,000 \\
. \\
5\end{array}$ & $\begin{array}{c}900^{*} \\
, 037 \\
5 \\
\end{array}$ \\
\hline & $\begin{array}{l}\text { Realized overnight stays - } \\
\text { number Total }\end{array}$ & $\begin{array}{c}\text { Correlation Coefficient } \\
\text { Sig. (2-tailed) } \\
\mathrm{N} \\
\end{array}$ & $\begin{array}{c}900^{*} \\
, 037 \\
5 \\
\end{array}$ & $\begin{array}{c}1,000 \\
5 \\
5\end{array}$ \\
\hline & $\begin{array}{l}\text { Favorable geographical and } \\
\text { transport position }\end{array}$ & $\begin{array}{l}\text { Correlation Coefficient } \\
\text { Sig. (2-tailed) } \\
\mathrm{N} \\
\end{array}$ & $\begin{array}{c}975^{* *} \\
, 005 \\
5 \\
\end{array}$ & $\begin{array}{c}872 \\
, 054 \\
5 \\
\end{array}$ \\
\hline & $\begin{array}{l}\text { Accessibility to national and } \\
\text { international programs } \\
\text { supporting the development of } \\
\text { the sector }\end{array}$ & $\begin{array}{l}\text { Correlation Coefficient } \\
\text { Sig. (2-tailed) } \\
\text { N }\end{array}$ & $\begin{array}{c}, 900^{*} \\
, 037 \\
5\end{array}$ & $\begin{array}{c}1,000^{* *} \\
\cdot \\
5\end{array}$ \\
\hline & $\begin{array}{l}\text { The economic situation and the } \\
\text { impact on tourism }\end{array}$ & $\begin{array}{l}\text { Correlation Coefficient } \\
\text { Sig. (2-tailed) } \\
\mathrm{N} \\
\end{array}$ & $\begin{array}{c}800 \\
, 104 \\
5 \\
\end{array}$ & $\begin{array}{c}900^{*} \\
, 037 \\
5\end{array}$ \\
\hline & $\begin{array}{l}\text { Degree of economic activity of } \\
\text { private entrepreneurs }\end{array}$ & $\begin{array}{l}\text { Correlation Coefficient } \\
\text { Sig. (2-tailed) } \\
\text { N }\end{array}$ & $\begin{array}{c}949^{*} \\
, 014 \\
5\end{array}$ & $\begin{array}{c}949^{*} \\
, 014 \\
5\end{array}$ \\
\hline
\end{tabular}

Sourse: Author'scalculations.

\section{Conclusion}

The South-Western region is an attractive place for cultural, SPA / balneo, eco and mountain tourism. The main competitors in the region when choosing a destination for specialized tourism are the tourist destinations in Greece and the Republic of Turkey. [8,10]The proposed tourist destination in the whole South-Western region is of high quality and is appreciated very well by consumers. The "satisfaction" indicator is stable over time. Foreign tourists are loyal to the destination and would not hesitate to recommend it as a place for specialized types of tourism. Roads and traffic remain a problem area, and it is possible for them to become a threat to the development of specialized types of tourism in the region.

The information and advertising of the South-Western region as a destination for specialized types of tourism is defined by the tourists as insufficient. $[12,16]$

The main problems are:

Insufficient cleanliness in the facilities, which provokes criticism from tourists. Lack of satisfaction with the low culture of service and etiquette.

The following can be said as recommendations: 
When offering specialized types of tourism, it is good to focus on the adventure.

It is important to emphasize the uniqueness in its various forms of nature, special experience, additional services."Adventure" element in the package can be cultural tourism. This would improve the attractiveness of the Bulgarian tourist service and would increase the average daily expenses of the tourists in the country.[11]

In the case of SPA / balneal packages and packages for rural tourism, the following must be taken into account: the desire for staticity and the purpose of these types of rest - "anti-stress" and "relaxation". If an adventure / provocative element is offered, it must be within the same locality. In the case of "eco" packages, the need for "adventure" in the holiday must be taken into account. Eco and cultural tourism are perceived in a similar way, so it is advisable to think about combining them. Both types of tourism are united by the concept of "adventure" vacation. The South-Western region retains its leading position among the other regions of level 2 in the country in terms of basic economic indicators (Gross Domestic Product-GDP, Gross Value Added-GVA, Foreign Direct Investment-FDI) in 2007-2010.

The only region in the country where the GDP per capita in the period 2007-2010 registered a continuous increase.

The produced GDP only in the region of Sofia (capital) exceeds three times the value of the South Central region, which ranks second after the South-Western region among the regions of the 2nd level.

Compared to other European regions, the South-Western region (SWR) is in a more favorable condition than other Bulgarian regions, but the level of economic development still reached is below the EU average.

In the structure of the economy of the south-western region by sectors, services at the expense of the industrial and agricultural sectors have a strongly predominant and growing share.

Despite the leading place of the South-Western region in the structure of distribution of foreign direct investments with accumulation in the country, in 2009 and 2010 in the region

The region occupies a leading position in terms of economic activity among the regions in the country, as for the period 2009-2011 a trend is registered. Expenditure on research and development in the region is rising, both in absolute terms and as a percentage of GDP, as in the South-West. Although slowly, the region is approaching the EU's first national commitment to the EU's Europe 2020 strategy (R\&D expenditure in SWR as a percentage of GDP in $2010-1.0$ per year). Dominance of the number of micro companies and small enterprises over medium and large enterprises in SWR - a trend typical for the whole country; share of micro companies over $90 \%$ of all enterprises in the region;

The largest concentration of enterprises in the middle region of level 2 is in the southwestern region - from $37 \%$ to $44 \%$ of the various low-sized enterprises, as in the period 2008-2011 the charter difference from other regions in the country, the number of enterprises in the southwestern region of growth.

SWR has a significant tourist potential, as well as a relatively constant contribution to the tourism sector of Bulgaria during the period 2007-2011.

Over the last 5 years, the region has $13-14 \%$ of the accommodation base and realized $13-15 \%$ of the tourist nights, keeping its third position after the South-Eastern region and the North-Eastern region; 19.4\% of the revenues from the overnight stays on the page from 2011 are on the territory of the South-Western region.

There is a slow recovery of the tourism sector in the southwestern region from the economic crisis that began in 2009 - a slight increase in overnight stays and revenues from them in the period 2010-2011.

Significant intra-regional inequalities are reported between Sofia district (capital) and the other 4 districts in the SouthWestern region - Sofia district (capital) makes up $82 \%$ of the GDP of the region and 39\% of national GDP; the value of GDP per capita for each of the districts of Kyustendil and Pernik is 4 times lower than that of the district of Sofia (capital); $87.2 \%$ of all FDI with accumulation, realized in the South-Western region, are in Sofia district (capital) - the region surpasses the other 5 regions from level 2 in the country, taken together; the greatest contribution in tourism in the SouthWestern region has again the region of Sofia (capital), followed by the region of Blagoevgrad, and the smallest - the region of Pernik;

Utilization of the local tourist potential

The qualities of "uniqueness", "attractiveness" and "mass consumption" make the tourist products marketable, and the tourist branch - a desirable, dynamic company. Numerous studies on tourist planning establish and confirm an exceptionally rich and diverse recreational and tourist route. Over the last two decades, the "formula" of regional tourism has remained unchanged: "business - spa tourism". The volume of realized overnight stays in the business center (Sofia), the ski centers (Bansko and Samokov) and the balneological center (Sandanski) forms $85 \%$ of the total for the region. All other municipalities (31 out of 35 with registered tourist activity) contribute $15 \%$ in the sector. At the same time, a significant potential for the development of alternative forms of tourism remains untapped. The unique thermo-mineral resource of the region is insufficiently utilized. ${ }^{1}$.

Despite established traditions, reported development and favorable factors, tourism in the region "recognizes" insurmountable weaknesses: poorly developed tourism product, underdeveloped network of companies charter services and supplies in tourism, insufficiently qualified personal in the field of tourism services limited access to natural and sport facilities, poor accommodation.[22,23]

The goal for the use of the tourist resources will be achieved with actions in three directions: 1) Improvement of the infrastructure - transport, engineering, engineering; 2) Preservation, preservation and improvement of the quality of the tourist resources - natural, cultural and anthropogenic; 3) Institutional coordination - between administrations and companies in tourism. [3]

\footnotetext{
${ }^{1}$ Nearly $50 \%$ of the national mineral water resource, in over 30 locations
} 
Non-utilized opportunities for sustainable development of regional tourism in all its forms are hidden in the formation of cluster structures. Preferences for the following tourist clusters are expressed:

- $\quad$ Cluster "Ski Tourism" - including the prominent ski destinations Bansko, Borovets and area "Vitosha";

- Cluster "Balneology and SPA" - Sandanski, Kyustendil, Velingrad, Sapareva Banya, Gorna Banya, Ovcha Kupel, Bankya, Kostenets, etc .; The localizations with thermo-mineral springs in the region are over 30 and can form an even network of balneological centers. At the moment, most of them have underdeveloped potential.

The main efforts / actions should be focused on:

- Development of attractive objects of natural and cultural heritage - restoration, preservation, exposure, equipment, animation;

- $\quad$ Development of skiing and all other forms of winter tourism;

- $\quad$ Improving the access and the adjacent tourist infrastructure;

- $\quad$ Formation and marketing of regional tourist products;

- $\quad$ Promotion of natural and cultural heritage; [24,25]

In addition to the formation of regional tourist clusters, the key to successful implementation of the goal is also organizational actions such as the formation of regional and local tourist and local partnership and between communities. Measures and projects in this area will rely on funding from the Operational Program Regional Development, Priority Axis 4: "Regional Tourism".[26,27]

\section{References:}

1. Wilde, A., Nowak, A. (2018). Total Supplier Risk Monitoring Knowledge Management as a Basis of a Preventive Supplier Evaluation. Journal of Business Management and Economics, 10(4), 711-788.

2. Khedhaouria, A., Nakara, W.A., Gharbi, S., Bahri, C. (2020). The relationship between organizational culture and small firm performance: Entrepreneurial orientation as mediator. European Management Review, 17(2), 515-528.

3. Dvorsky, J., Petrakova, Z., Khan, K.A., Formanek, I., Mikolas, Z. (2020). Selected aspects of strategic management in the service sector. Journal of Tourism and Services, 20 (11), 109-123.

4. Sipa, M. (2017). Innovation as a key factors of small business competition. European Journal of Sustainable Development, 6(1), 344-356.

5. Chaffey, D., Chadwick, F.E., Johnson, K., Mayer, R., (2008). Internet Marketing: Strategy, Implementation and Practice. Pearson Education.

6. Dawson, C. (2002). Practical Research Methods: A User Friendly Guide to Mastering Research Techniques and Projects. Howtobooks.

7. Jupp, V. (2006). The Sage Dictionary of Social Research Methods. SAGE Publications.

8. Hair, J.F., Bush, R.P., Ortinau, D.J. (2003). Marketing Research Within a Changing Information Environment. McGraw-Hill/Irwin

9. Kalof, L., Dan, A., Dietz, Th. (2008). Essentials of Social Research. New York: Open University Press..

10. Kothary, C.R. (2004). Research Methodology, Methods \& Techniques. New Delphi: New Age International Limited Publishers.

11. Wu, D., Song, H., Shen, S. (2017). New developments in tourism and hotel demand modeling and forecasting. International Journal of Contemporary Hospitality Management, 29(1), 507-529.

12. Dimitrov, P. (2013). Forecasting the number of tourist arrivals in Southwest Bulgaria. TMS Conference Series, Strategies in tourism organizations and destinations, 141-152.

13. Moisander, J., Valtonen, A. (2006). Qualitative Marketing Research: A Cultural Approach. SAGE Publications.

14. Sounders M., Lewis Ph., Thornhill A. (2000). Research Methods for Business Students. Prentice Hall, pp. 19-32.

15. Beqiri, M., Borici, A., Borici, A., Dergjini, A. (2014). An Empirical Study of Service Quality Factors Impacting Tourist Satisfaction and Loyalty: Velipoja Tourist Destination. TMC Academic Journal, 8(2), 36-48.

16. Ünal, A., Celen, O. (2020). Expectations of Domestic Tourists Before Destination Selection and Their Post-Purchase Evaluations: Igneada Case. Journal of Management and Economic Studies, 2(2), 112-128.

17. Eren, S., Kozak, N. (2018). Competitive Positioning of Winter Tourism Destinations: A Comparative Analysis of Demand and Supply Sides Perspectives-Cases From Turkey. Journal of Destination Marketing \& Management, 9 , 247-257.

18. Dvorsky, J., Kliestik, T., Cepel, M., Strnad, Z. (2020). The influence of some factors of competitiveness on business on business risks. Journal of Business Economics and Management, 21(5), 1451-1465.

19. Ahmedova, S. (2015). Factors for increasing the competitiveness of small and medium-sized enterprises (SMEs). In S. Sener, E. Saridogan \& S. Staub (Eds.), World Conference on Technology, Innovation and Entrepreneurship (pp. 1104-1112). Amsterdam: Elsevier Science BV. 
20. Carroll, A.B., Buchholtz, A.K., (2008). Business \& Society: Ethics and Stakeholder Management. South-Western Cengage Learning.

21. Warren, F. K. (2010). Marketing Research Methods in SAS: Experimental Design, Choice, Conjoint and Graphical Techniques, SAS 9.2 Edition MR-2010, SAS Institute Incorporated, 63-67.

22. Ledolter, J., Abraham, B. (1984). Some comments on the initialization of exponential smoothing. Journal of Forecasting, 3, 79-84.

23. Gardner, E.S. (1985). Exponential Smoothing: the state of art. Journal of Forecasting, 4(1), 1-28.

24. Veloso, C.M., Monte A.P. (2019). Validation of a measurement scale of service quality, image, customer satisfaction and loyalty in traditional trade. Tourism Management Studies Journal, 15(3), 27-35.

25. Akgunduz Y., Bardakoglu O., Koba Y. (2020). The effects of participant motivational behavioural intention: the MARBLE Case. Tourism Management Studies Journal, 16(3), 15 -22

26. Melo, F.V.S., Alenkar de Faria, S., (2018). Sustainability communication and its effect in consumer attention to visit a tourist destination. Tourism Management Studies Journal, 14(2), 36-44.

27. Dimitrov P., Krasteva R., Dimitrov B., Parvanov P. (2018). Bulgarian Tourism and the problem of poverty in Bulgaria. Tourism Management Studies Journal, 14(2), 45-52. 